\title{
Two of Constantine's "Official Lies"
}

\section{Stanislav Doležal}

\section{(University of South Bohemia in České Budějovice)}

\begin{abstract}
The article deals with the twin lie, devised by the Emperor Constantine the Great in 310: his fake ancestry (his relationship to the Emperor Claudius Gothicus) and his alleged "pagan vision" of Apollo (which was either a lie or, perhaps less probably, a product of hallucination). Both lies served to buttress his shaken political position in that year and to provide him with a hereditary claim to rule. This claim was presented as superior to the tetrarchic principles of succession which were already flouted by Constantine in 306 by his usurpation, and to his elevation to the position of augustus by Maximian in 307. In contrast, the story of the famous "Christian vision" was most probably fabricated by Eusebius after Constantine's death and bears no relation (not even a resemblance) to the "pagan vision" of Constantine.
\end{abstract}

\section{Keywords}

Constantine the Great; Claudius Gothicus; Apollo; vision 
In the preceding volume of Graeco-Latina Brunensia, ${ }^{1}$ this author dealt with the unverifiable claim of Constantine the Great that his father, the Emperor Constantius I, conferred upon him the imperial title before he died. This claim cannot be proved now (and it could not be proved in 306) and it appears to be suspect. It rested solely on Constantine's assertion, and it is found in some, but not all of our sources. ${ }^{2}$ However, it did have its intended political impact. Galerius, the senior Emperor of the Tetrarchy, probably trying to avoid an unnecessary war and lacking any strong rationale to reject this claim, recognized Constantine as the Western caesar, thus making him the fourth member of the imperial college by order of precedence. Thus a splendid career of a successful Emperor was started, based on a lie. Nonetheless, this lie helped conceal his successful usurpation on 25 July 306.

In politics, we always enter the world of appearances, assertions and lies. Political lies are not confined to any particular era, nation, or political system. A lie is a simple, but a very useful tool to every politician. In the case of Constantine, lying almost seems to be an elephant in the room - an issue no one wants to touch. The present author found it very refreshing that the word "lie" was connected with Constantine and his policies at least by Timothy D. Barnes, probably the most influential Constantinian scholar. Barnes listed some of Constantine's lies, which he called “official lies", e. g., lies designed to strengthen Constantine's political position. This was a groundbreaking approach. For example, Barnes remarked that some scholars "found it hard to believe that Constantine lied about his age." And yet the Emperor clearly did lie in this case, or at least condoned a lie about his age that was spread by contemporary sources that were close to him. ${ }^{4}$ However, Barnes himself was not unbiased. For example, he was led into thinking (influenced by Lactantius) that Constantine was "long groomed for the throne" under the first Tetrarchy and therefore, that his accession in 306 was legal and just. ${ }^{5}$ In reality, it was not. Constantine was a typical Roman usurper. ${ }^{6}$ After the death of his father, he staged a military coup and claimed the imperial title for himself. He may have even

1 Doležal (2019: pp. 19-32).

2 See Doležal (2019: p. 27) for details.

3 Barnes (2014: p. 3).

4 Although Constantine was most probably born in 272 (see the present author's forthcoming article Kdy se narodil Konstantin Veliký? - Doležal, forthcoming), no less than five different sources state that Constantine was young in 306 or even at a later point: Lact. mort. pers. 18, 10 (adulescens in 305); 24, 4 (iuvenis in 306); 29, 5 (adulescens in 310); Pan. Lat. VII (6), 5, 3 (imperator adulescens in 307); Pan. Lat. IV (10), 16, 4 (tu, imperator optime, inito principatu, adhuc aevi immaturus sed iam maturus imperio, i. e., in 306); Pan. Lat. VI (7), 21, 6 (iuvenis in 310); Euseb. VC I, 19 and VC II, 51.

5 Barnes (1981: p. 28); cf. Idem (2014: p. 47) (an heir presumptive to the imperial purple); Lact. mort. pers. 19, $1-5$.

6 To be sure, some scholars would protest to this simple assertion, e. g., Odahl (2013: p. 79), Stephenson (2010: pp. 116-117), Leadbetter (2009: p. 165) and, most vocally, Barnes (2014: p. 63; 1981: p. 28) ("Constantine could only be called a usurper on the most tendentious of definitions"). But the majority of scholars would agree that what happened on 25 July 306 was an usurpation of imperial power (Girardet 2010: p. 27; Van Dam 2008: p. 36; Humphries 2008: p. 100; Lenski 2007: p. 62; Clauss 1996: p. 22; Pohlsander 2004: p. 16; Drake 2000: p. 166; Češka 2000: p. 47), although some appear to be undecided on this matter (Potter 2013: p. 112; Southern 2004: p. 170). 
shown reluctance to accept this honour (the so-called refutatio imperii or recusatio imperii was a well-established tradition by that time). ${ }^{7}$ In 306, Constantine quickly became a politician, and a very astute one. And he was tremendously successful in his early reigning years. By the end of 306, probably without spilling a single drop of blood, he secured his father's domain (Britain, Gaul and Spain) and gained the legitimacy from Galerius to rule these parts of the Empire. There were now two augusti (Galerius and Severus) and two caesares (Maximinus and Constantine) and thus the "third Tetrarchy" was formed. The lie of the year 306 may have been the first "official lie" of Constantine, but certainly not the only one, and this article deals with Constantine's twin political lie of the year 310. But first, a brief outline of political affairs in 306-310 is necessary.

After accepting the title of caesar from Galerius in autumn 306, Constantine became the legitimate ruler of Gaul, Britain and Spain. In 307, he decided to accept the title of augustus from Maximian who also gave him his daughter Fausta in marriage. Maximian claimed for himself the imperial power for the second time, after his son Maxentius had rebelled in late 306 in Italy, proclaiming himself Emperor. Thus in 307, four Emperors ruled the West, two of them legitimate (Severus, Constantine), two of them not (Maximian, Maxentius). Constantine accepted Maximian's offer at the cost of losing his legitimate status in the East where Galerius and Maximinus stopped considering him a member of the imperial college at all. In the view of Galerius, he lost the title of caesar and any shred of legitimacy with it. Admittedly, it was a risky venture for Constantine but it seemed safe enough at the time, because after Severus died (in a failed campaign aimed to remove Maxentius), all three remaining Emperors in the West - Maximian, Maxentius and Constantine - were now allies. In 308, at the conference of Carnuntum, an officer named Licinius became the new Western augustus while Maximian was once again ousted from the imperial college by the will of Galerius (and with the consent of Diocletian who was present as a special guest) and agreed to retire for the second time. Constantine was promoted again to the status of caesar, gaining his legitimacy again. This was his second political victory since 306. With Maxentius still considered a usurper, there were now only two augusti (Galerius and Licinius) and two caesares (Maximinus and Constantine) in the Empire. Thus the "fourth Tetrarchy" was formed. ${ }^{8}$

Constantine was shrewd enough to accept the title of caesar from Galerius for the second time; however, in his domains he considered himself an augustus. In 310, however, his political position suddenly became precarious. Everything he did since 306 was seriously jeopardized by his father-in-law's sudden usurpation. In a surprising move, Maximian had himself elevated by some soldiers to the rank of augustus again. Constantine quickly subdued Maximian, putting him to death (or forcing him to commit suicide), but his own position now became vulnerable. By eliminating his father-in-law, his source of legitimacy in the West as an augustus was removed. Worse still, he had no ally. His imperial colleagues were now either his enemies (Maxentius) or potential enemies (Licinius, Maximinus). As for Galerius himself, in 309 he had bestowed on Constantine a hollow

7 Pan. Lat. VI (7), 8, 2-4.

8 See Barnes (2014: p. 89) for a detailed overview. 
title filius augustorum, "a son of the augusti", to make up for the title augustus, which was denied to Constantine for obvious reasons. In the worst possible scenario, Constantine faced the prospect of losing his recognition as augustus with his subjects and of being overwhelmed by his enemies. This serious crisis called for using every political tool available to Constantine. He needed to find another source of legitimacy in the West, and if possible, some allies. And so, in 310, an interesting speech was delivered in Trier. ${ }^{9}$

\section{Choosing an ideal forefather}

The speech was "surely delivered soon after Maximian's death" ${ }^{10}$ and although the anonymous speaker did elaborate on the insurrection of Maximian, this recent event was an awkward matter; after all, Maximian was not only Constantine's father-in-law but also one of his trusted courtiers. No wonder that Maximian is depicted "as a demented monster of ingratitude", as Barnes put it. ${ }^{11}$ More importantly, the speaker (no doubt with Constantine's permission and probably instructed by him) told his audience about the relationship of Constantine to the famous Emperor of the 3rd century, Claudius Gothicus (who ruled in 268-270). No details are supplied. Constantine is simply depicted as a member of a ruling family that now includes three Emperors - Claudius Gothicus, Constantius I and Constantine. This is a forged ancestry, as nowadays virtually every scholar concedes, and the genealogical fraud is another of Constantine's political or "official" lies. That being said, it is a cleverly devised lie. The rule of Claudius was short and probably few details about his family were widely known forty years after his death. More to the point, Claudius had been approved by the Roman senate, he was not assassinated (but died of a plague), was not involved in his predecessor's assassination (Gallienus fell victim to a conspiracy of Roman officers), and his success against the Gothic invasion of 269 was enormous and duly celebrated. ${ }^{12}$ These factors combined made him a suitable progenitor. In comparison, his successor Aurelian would be a much more controversial choice. ${ }^{13}$ The purported ancestry was presented to the public as Constantine's right to rule that was superior to the tetrarchic principles of succession (which were already flouted by Constantine in 306 by his usurpation) and to his elevation to the rank of augustus by Maximian in 307.

The question that may have vexed Constantine at this point is how the lineage should be construed. The speech does not give a clue; but its vague expression avita cogna-

9 Or possibly in Arles (Barnes 2014: p. 72). The speech in question is Pan. Lat. VI (7).

10 Nixon \& Rodgers (2015: p. 213). Perhaps only “a few weeks later” (Barnes 2014: p. 72).

11 Barnes (2014: p. 72).

12 Many later authors mention his victory at Naissus, see Eutr. IX, 11; Aur. Vict. 34; Zos. I, 41-46; Oros. Hist. VII, 23.

13 Aurelian is said by some of our Christian sources (including Constantine himself) to have initiated (or planned) a persecution of Christians (Constantini imperatoris oratio ad coetum sanctorum 24; Jord. Rom. 290; Oros. Hist. VII, 23, 6; Hieron. Chron. s. a. 275; Euseb. HE VII, 30, 21; Lact. mort. pers. 2-6 a 12-16). Moreover, he had a reputation of greed (Amm. Marc. XXX, 8, 8) and cruelty (Eutr. IX, 14; HA, Aurel. 37, 1). 
tio could scarcely have been interpreted in the sense that Claudius was Constantine's grandfather - he would have to be the father of Constantius in that case: but whoever listened to the speech probably knew who Constantius' real father was. Although we do not know the names of Constantius' parents, Barnes believed that they were named Flavius Dalmatius and Julia Constantia, which is plausible. ${ }^{14}$ In contrast, the full name of Claudius Gothicus was Marcus Aurelius Valerius Claudius. Moreover, Aurelian would scarcely have let Constantius live, if the latter was the son of Claudius Gothicus. Therefore, the expression avita cognatio was probably meant to be understood more generally, as an unspecified blood kinship. ${ }^{15}$ Similarly, in a speech delivered in 311 in Trier, another anonymous speaker in reference to Constantine repeatedly mentioned "the deified Claudius, your ancestor" (divum Claudium parentem tuum), obviously without any intention to imply that the word parens should signify Constantine's father. ${ }^{16}$ Why so vaguely? Was it because in 310 and 311, there were still people alive who remembered not only Constantius, but also Claudius? Equally mysterious are two inscriptions from Italy, made in 312 or shortly thereafter, speaking of Constantine as either grandson or descendant of Claudius, ${ }^{17}$ or coins issued by Constantine in 317 and 318, bearing the legend DIVO CLAUDIO OPTIMO IMP[ERATORI], i. e. "For the best Emperor, the deified Claudius," 18 or a poem by Publilius Optatianus Porfyrius, written probably in $319 .{ }^{19}$ None of these sources reveals the exact relationship between Constantine and Claudius.

Having defeated Licinius for the second time in 324 and thus ruling the whole Roman world ever since, Constantine refrained from reminding his subjects about his famous forefather. The need for a famous ancestor simply diminished as there were no enemies or rivals to compete with. The sources written after Constantine's death, while continuing to mention this purported ancestry, introduced an interesting innovation. They tell us that Constantius was the grandson (or grandnephew) of Claudius, inserting thus one more generation into the family tree. The Origo Constantini imperatoris says that Constantius was "the grandson of the brother of the best Emperor, deified Claudius" (Constantius, divi Claudi optimi principis nepos ex fratre).${ }^{20}$ Eutropius slightly differs, asserting that Constantius "is said to have been the grandson of Claudius through his daughter" (Constantius per filiam nepos Claudi traditur). ${ }^{21}$ It is obvious that this revised genealogy presents

14 Barnes (1982: p. 36).

15 Pan. Lat. VI (7), 2 (a primo igitur incipiam originis tuae numine, quod plerique adhuc fortasse nesciunt, sed qui te amant plurimum sciunt. Ab illo enim divo Claudio manat in te avita cognatio).

16 Pan. Lat. V (8), 2, 5 and 4, 2.

17 ILS 699 (divi Claudi nepoti), ILS 702 (nepos divi Claudi). Just like the expressions avita cognatio and parens, the word nepos can have more meanings ("grandson" or "descendant").

18 Bruun (1966): p. 180 (Trier, year 318); p. 252 (Arles, year 318); p. 310 (Rome, 317-318); p. 429 (Siscia, 317-318); p. 502 (Thessalonica, 317-318).

19 Optat. Carm 10, 29-31 (atavo summo melior! cui Claudius acer, magnanimum sidus, dat clarum e numine divo imperium).

20 Origo 1, 1.

21 Eutr. IX, 22, 1. Translation: Bird (1993: p. 61). This view is held by Hieronymus (Chron. s. a. 290: Constantius Claudii ex flia nepos fuit) and Jordanes (Rom. 298). Historia Augusta is rather schizophrenic on this issue, saying that Constantius was the grandson (HA, Claud. 9, 9: ut iam tunc Constantio Caesari nepoti 
grave chronological problems: if Constantine was born in 272 and his father Constantius in around 240, then Claudius or his brother would have to be born impossibly early - in around 200 or even earlier. ${ }^{22}$ Perhaps most interestingly, the Emperor Julian, who must have known his own lineage well, although he repeatedly admitted that Claudius was his famous ancestor, never revealed the latter's exact position in the Constantinian family. ${ }^{23}$

It is perhaps important to stress the fundamental difference between the forged ancestry of Constantine and mythical or historical-fictitious genealogies and founding stories, of which there are many examples in antiquity (e. g., the Argead dynasty of Macedon, whose members claimed descent from Heracles). In sharp contrast to them, Constantine's bogus genealogy was a hastily devised, ad hoc, fake genealogy, concocted in a time of political crisis. It can even be asserted that had Maximian not rebelled against Constantine in 310, this fake genealogy would perhaps never have been construed - it simply would not have been needed. Perhaps it is best compared with the case of Septimius Severus who around 196 formally adopted himself into the family of Marcus Aurelius, thus becoming the brother of Commodus, who in turn was deified (divi Marci pii filius, divi Commodi frater). According to Pat Southern, "Severus sought for a firmer foundation for his supremacy, and also for a guarantee of survival for the dynasty he intended to establish. Continuity with the short-lived regime of Pertinax was important when he entered Rome for the first time as Emperor, but now he needed deeper roots. Marcus Aurelius was the last known respectable and respected Emperor, whose achievements and solid Roman attitudes were worth emulating, so Severus announced his connections with this Imperial house by declaring himself the son of Marcus". ${ }^{24}$ These words perfectly suit Constantine's case in $310 .{ }^{25}$

\section{Apollo as a divine protector}

In the same speech, in which Constantine's fake ancestry was divulged, another official lie was presented to the public. ${ }^{26}$ It was included in the narrative about Maximian's

futuro videretur Claudius) and grandnephew of Claudius (HA, Claud. 13, 1-2: Claudius, Quintillus et Crispus fratres fuerunt. Crispi f[am]ilia Claudia; ex ea et Eutropio, nobilissimo gentis Dardanae viro, Constantius Caesar est genitus); cf. HA, Claud. 1, 1; 1, 3; 10, 7.

22 According to PLRE I (Claudius 11, p. 209), Claudius was born "possibly in 214".

23 Julianus, Oratio 1, 6 D; idem, Oratio 2, 51 C; idem, Caesares 12. It is also noteworthy that the later Christian sources know nothing of this ancestry, e. g. Orosius (Hist. VII, 25, 16).

24 Southern (2004: p. 35). Cf. Potter (2004: p. 110).

25 One of Severus' courtiers congratulated the emperor with sarcasm on his enrollment in the family of Marcus Aurelius, saying that the Emperor "finally found a father" (referring to his insignificant lineage, see Dio LXXVI, 9, 4). To our knowledge, no one mocked Constantine for the fabrication of his descent. It is also noteworthy that another founder of a Roman imperial dynasty, the Emperor Vespasian, found efforts of some people to trace descent of his humble family to a companion of Heracles utterly ridiculous (Suet. Vesp. 12: Quin et conantis quosdam originem Flavii generis ad conditores Reatinos comitemque Herculis, cuius monimentum exstat Salaria via, referre irrisit ultro); see Levick (1999: p. 92). 
insurrection and its subsequent suppression by Constantine. The speaker paints a vivid picture of Constantine rushing south to Marseille to deal with Maximian's revolt and then equally rapidly returning to the Rhine where, as the Emperor heard, a Frankish incursion was in progress. Happily for Constantine, as soon as the Franks heard rumors about the Emperor's army marching against them, they retired. Constantine, therefore, could afford to march at more leisurely pace and even find a time to visit a temple. Making a detour from the via Agrippa (leading from Arles to Cologne), presumably at Nijon, he chose another way, leading to Reims. After about thirty kilometers, he got to present-day Grand, where Apollo's temple stood, "the most beautiful temple in the whole world", according to the speaker who describes a strange phenomenon experienced by the Emperor during this stopover: "For you saw, I believe, O Constantine, your Apollo, accompanied by Victory, offering you laurel wreaths (Apollinem tuum comitante Victoria coronas tibi laureas offerentem), each one of which carries a portent of thirty years. For this is the number of human ages which are owed to you without fail - beyond the old age of a Nestor. And - now why do I say ,I believe‘? - you saw, and recognized yourself in the likeness of him (vidisti teque in illius specie recognovisti) to whom the divine songs of the bards had prophesied that rule over the world was due. And this I think has now happened, since you are, O Emperor, like he, youthful (iuvenis), joyful, a bringer of health and very handsome." Despite its ambiguous expressions, the message is clear enough: just like Constantine's purported ancestry, his "pagan vision" was designed to support his shaken political position and to provide him "with both a unique hereditary claim to rule... and divine sanction to be emperor of the whole empire". ${ }^{27}$ There may even have been a kernel of truth in the story: physical fatigue resulting from a forced march, coupled with lack of sleep and other factors may have caused hallucinations in Constantine. ${ }^{28}$ There is certainly no need to postulate that Constantine experienced some kind of optical phenomenon, such as halo. ${ }^{29}$ Such things simply do not happen on demand. If the whole event can be explained more easily and "economically" by either a hallucination or a lie, then we have a solution to this problem that is both simple and plausible. The truth is that in 310 Constantine desperately needed a famous ancestor, and that he found one; and that he also needed a divine protector, and that he also found one. And it must be stressed again that had Maximian not rebelled against Constantine, there would have been no pressing need for such heavenly protection.

27 Nixon \& Rodgers (2015: p. 215).

28 For causes of hallucinations see, for example, Teeple \& Caplan \& Stern (2009).

29 Weiss (2003). This hypothesis was accepted by Barnes (2014: pp. 74-80), Mitchell (2015: pp. 278-280) and Lenski (2007: pp. 67-72), but not by Pohlsander (2004: pp. 23-24), Clauss (1996: p. 35), Southern (2004: p. 175) or Stephenson (2010: p. 188) who considered the event to be "a pious fiction". 


\section{Constantine's visions}

This "pagan vision" of Constantine is sometimes linked to another purported "vision" of his - the more famous "Christian vision", which is described by Eusebius alone. ${ }^{30}$ In his Life of Constantine, he claims that Constantine saw a sign in the sky, "a cross-shaped trophy formed from light", even with a text attached to it. We are not told when or where Constantine had this vision; it may have been in 312 or indeed earlier: Eusebius is (perhaps deliberately) vague on the issue of time and place here. Eusebius simply wrote that amazement seized both Constantine "and the whole company of soldiers which was then accompanying him on a campaign he was conducting somewhere". ${ }^{31}$ Eusebius next explains that in the following night, when the Emperor was sleeping, "the Christ of God appeared to him with the sign which had appeared in the sky, and urged him to make himself a copy of the sign which had appeared in the sky, and to use this as protection against the attacks of the enemy". ${ }^{22}$ It must be stressed that Lactantius in his treatise De morte persecutorum (written in about 315) knows nothing of this story (except for the dream) and Constantine himself in his speech Oratio ad coetum sanctorum (composed some time in 315-325) knows nothing of it either. Even Eusebius' earlier Historia ecclesiastica, whose final edition was published in about 325 (with some finishing touches made in 326), contains no trace of this strange story. ${ }^{33}$

Needless to say that apart from literary sources there is no other evidence of either vision of Constantine. Notwithstanding his personal conversion to Christianity in 312, the Emperor still used for his coins and inscriptions the language of religious ambiguity. ${ }^{34}$ Christian symbols, as Hans Pohlsander rightly put it, are slow to appear on his coins. ${ }^{35}$ Mars and Sol Invictus were frequently used, among other pagan deities. ${ }^{36}$ The famous silver medallion of Ticinum, minted probably in 315, with a Christian symbol (the ChiRho or christogram) is riddled with ambiguities and its interpretation remains problematic. ${ }^{37}$ At best, it points to the use of christogram, but not to any vision of Constantine. Similarly, another medallion from Ticinum, a large gold one, minted in 313, in which

30 That is, if we ignore all the sources that take up and further embellish this story of his (e.g., Socr. $H E \mathrm{I}$, 2; Soz. HE I, 3; and Philost. HE I, 6).

31 Euseb. VC I, 28 (translation by Cameron \& Hall 1999: p. 81).

32 Euseb. VC I, 29 (translation by Cameron \& Hall 1999: p. 81).

33 For the history of editions of the HE, see Burgess (1997: pp. 501-502), Barnes (1981: pp. 148-163) and Louth (1990: pp. 111-113).

34 The Arch of Constantine, completed in 315, is perhaps the best example of this neutrality (see Lenski 2008).

35 Pohlsander (2004: p. 27).

36 For Constantine's favourite pagan deities on coins, see Sutherland (1967: pp. 39-43) (cf. Potter 2013: p. 177). Sol Invictus appears on Constantine's coins as late as in 320s, see Barnes (2014: p. 18).

37 For example, Bleckmann (2007: p. 20) ("Whether the images behind the shield are really supposed to represent a Christian cross-scepter remains a subject of debate") and Clauss (1996: p. 102) ("Was auch immer das Zeichen am Helm bedeuten sollte, es war mit bloßem Auge kaum zu erkennen”). For an extensive list of all associated problems see Wienand (2012: pp. 265-270), and cf. Girardet (2010: pp. 80-82). 
Constantine is portrayed in double profile with a deity which may be either Sol Invictus or Apollo, obviously cannot serve as evidence for the "pagan vision" of Constantine. ${ }^{38}$

The existence of two different visions of Constantine "caused deep disquiet and suspicion" among the scholars, as Barnes put it. ${ }^{39}$ Accordingly, some scholars tried to get rid of one of them. Barnes argued, for example, that the "Christian vision" never happened: that it was still the earlier "pagan vision" (interpreted by Barnes as a halo), to which Constantine "only later gave a Christian interpretation". ${ }^{40}$ Stephenson concurred that the "Christian vision" was, "in fact, a clever retelling of the vision of Apollo", differing in that he did not believe that Constantine saw anything in Gaul in 310. ${ }^{41}$ Indeed, the story of the "Christian vision" bears no relation (not even a resemblance) to the "pagan vision", which itself was either a product of hallucination or a lie. Although Eusebius appeals to Constantine's personal testimony, he composed his Life of Constantine only after Constantine's death and he was probably unaware of the vision of Apollo. ${ }^{42}$ Even if he was familiar with it, the story he concocted is not only fundamentally different from it, but also much more clumsy. A personal vision at (or in?) a temple is one thing, a show in the sky with many witnesses standing around is another. ${ }^{43}$ The logical conclusion is that these stories are unrelated, the first one being Constantine's "official lie" from 310, and the other one a fabrication devised by Eusebius in around 338. This view is best summed by Cameron and Hall: "When Eusebius made the final revisions to HE, after the victory and before the Council, he did not insert anything about a vision. When he composed the $V C$, however, Eusebius needed a miracle for his portrayal of Constantine..." ${ }^{44}$ Simply put, Eusebius in all probability knew nothing of the "Christian vision" until around 338, when he himself invented it. To which we may add that it is also highly improbable that Eusebius heard the story from Constantine during the Council of Nicaea because otherwise he

38 Sutherland (1967: pp. 277-278). An almost identical medallion was minted in Ticinum in 315 (Bruun 1966: p. 363; see also Plate 9, No. 32). The identity of this deity is hotly debated, see for example Drake (2000: p. 182), Stephenson (2010: pp. 157-158) and Clauss (1996: pp. 102-103).

39 Barnes (2014: p. 76). Nevertheless, some scholars have been willing to accept as genuine both the vision of Apollo and the story of Eusebius (for example, Odahl 2013: p. 105 or Nicholson 2000). For some of them, the "Christian vision" of Constantine seems to be almost an article of faith, cf. Liebeschuetz (1979: p. 278) who "cannot imagine it to have been invented".

40 Barnes (2014: p. 75), referring to Weiss (2003). This view was also shared by Mitchell (2015: p. 280), Lenski (2007: p. 71), Girardet (2010: pp. 35-40) and Potter (2013: pp. 157-158).

41 Stephenson (2010: p. 131) ("we may doubt that Constantine truly experienced a vision in Gaul”).

42 Eusebius may have known about the dream as described by Lactantius, see Lenski (2016: p. 56) ("elaborating on this story two decades later, Eusebius appears to have connected Constantine's solar vision with this dream and to have attributed both to the Christian god"). But obviously this changes nothing about the strong possibility of his fabrication of the "Christian vision". Cf. for example Wienand (2012: p. 179, note 119, and p. 258, note 231) who doubts that Eusebius in his VC, Lactantius and Panegyricus VI (7) all point to the same event.

43 Pohlsander (2004: p. 24) asks the right question: "If the phenomenon was observed by the entire army, why then was it not more widely known?” Already A. H. M. Jones (1948: p. 96) tried to address this problem by supposing that the phenomenon "may well have been less conspicuous than Constantine imagined it later to have been".

44 Cameron \& Hall (1999: p. 204); cf. ibid. (p. 205): "it seems more likely that the account is new in the VC". 
would have included it into his narrative in the $H E$, when he was revising it for the last time in 326.

No wonder some scholars put no stock in either story of vision and prefer the much more believable version of Lactantius who simply mentions Constantine's dream before the battle with Maxentius. ${ }^{45}$ An ominous dream can happen to anyone and our credulity is not strained when we listen to someone's recollection of a dream. While today, to a rational person, an ominous dream is a mere nuisance, in the 4th century it could certainly be much more powerful - even to the extent that it could make an Emperor believe that he stands under protection of a god.

\section{Bibliography}

Barnes, T. D. (1981). Constantine and Eusebius. Cambridge, Mass. - London: Harvard University Press.

Barnes, T. D. (1982). The New Empire of Diocletian and Constantine. Cambridge, Mass. - London: Harvard University Press.

Barnes, T. D. (2014). Constantine. Dynasty, Religion and Power in the Later Roman Empire. Chichester: Wiley Blackwell.

Bird, H. W. (Transl.). (1993). Eutropius: Breviarium. Liverpool: Liverpool University Press.

Bleckmann, B. (2007). Sources for the History of Constantine. In N. Lenski (Ed.), The Cambridge Companion to the Age of Constantine (pp. 14-34). Cambridge: Cambridge University Press.

Bruun, P. M. (1966). The Roman Imperial Coinage, VII: Constantine and Licinius A.D. 313-337. London: Spink and Son Ltd.

Burgess, R. (1997). The Dates and Editions of Eusebius' Chronici Canones and Historia Ecclesiastica. The Journal of Theological Studies, 48(2), new series, 471-504.

Cameron, A., \& Hall, S. G. (Transl.). (1999). Eusebius: Life of Constantine. Oxford: Clarendon Press. Clauss, M. (1996). Konstantin der Große und seine Zeit. München: C. H. Beck.

Češka, J. (2000). Zánik antického světa. Praha: Vyšehrad.

Doležal, S. (2019). The Political and Military Aspects of Accession of Constantine the Great. Graeco-Latina Brunensia, 24(2), 19-32.

Doležal, S. (forthcoming). Kdy se narodil Konstantin Veliký? Auriga (ZJKF), 62(1).

Drake, H. A. (2000). Constantine and the Bishops. The Politics of Intolerance. Baltimore - London: The John Hopkins University Press.

Girardet, K. M. (2010). Der Kaiser und sein Gott. Das Christentum im Denken und in der Religionspolitik Konstantins des Großen. Berlin - New York: De Gruyter.

Humphries, M. (2008). From Usurper to Emperor: The Politics of Legitimation in the Age of Constantine. Journal of Late Antiquity, 1, 82-100.

Jones, A. H. M. (1948). Constantine and the Conversion of Europe. London: Hodder \& Stoughton Ltd. Jones, A. H. M., Martindale, J. R., \& Morris, J. (1971). The Prosopography of the Later Roman Empire, I: A.D. 260-395. Cambridge (= PLRE I).

45 Lact. mort. pers. 44, 5. See Pohlsander (2004: p. 24). 
Leadbetter, B. (2009). Galerius and the Will of Diocletian. London - New York: Routledge.

Lee, A. D. (2007). Traditional Religions. In N. Lenski (Ed.), The Cambridge Companion to the Age of Constantine (pp. 159-182). Cambridge: Cambridge University Press.

Lenski, N. (2007). The Reign of Constantine. In N. Lenski (Ed.), The Cambridge Companion to the Age of Constantine (pp. 59-90). Cambridge: Cambridge University Press.

Lenski, N. (2008). Evoking the Pagan Past: Instinctu Divinitatis and Constantine's Capture of Rome. Journal of Late Antiquity, 1(2), 204-257.

Lenski, N. (2016). Constantine and the Cities. Imperial Authority and Civic Politics. Philadelphia: University of Pennsylvania Press.

Levick, B. (1999). Vespasian. London - New York: Routledge.

Liebeschuetz, J. H. W. G. (1979). Continuity and Change in Roman Religion. Oxford: Clarendon Press.

Louth, A. (1990). The Date of Eusebius' Historia Ecclesiastica. The Journal of Theological Studies, 41(1), 111-123.

Mitchell, S. (2015). A History of the Later Roman Empire AD 284-641. Chichester: Wiley Blackwell.

Nicholson, O. (2000). Constantine's Vision of the Cross. Vigiliae Christianae, 54(3), 309-323.

Nixon, C. E. V., \& Rodgers, B. S. (2015). In Praise of Later Roman Emperors: The Panegyrici Latini. Berkeley - Los Angeles - Oxford: University of California Press.

Odahl, Ch. M. (2013). Constantine and the Christian Empire. London - New York: Routledge.

Pohlsander, H. A. (2004). The Emperor Constantine. New York: Taylor and Francis e-Library.

Potter, D. S. (2004). The Roman Empire at Bay AD 180-395. London - New York: Routledge.

Potter, D. S. (2013). Constantine the Emperor. Oxford: Oxford University Press.

Southern, P. (2004). The Roman Empire from Severus to Constantine. New York: Taylor and Francis e-Library.

Stephenson, P. (2010). Constantine: Roman Emperor, Christian Victor. New York: The Overlook Press.

Sutherland, C. H. V. (1967). The Roman Imperial Coinage, VI: From Diocletian's reform (A. D. 294) to the death of Maximinus (A. D. 313). London: Spink and Son Ltd.

Teeple, R. C., Caplan, J. P., \& Stern, T. A. (2009). Visual hallucinations: differential diagnosis and treatment. Primary care companion to the Journal of clinical psychiatry, 11(1), 26-32 [retrieved 02.10.2020 from https://doi.org/10.4088/pcc.08r00673].

Van Dam, R. (2008). The Roman Revolution of Constantine. Cambridge: Cambridge University Press.

Weiss, P. (2003). The Vision of Constantine. The Journal of Roman Archaeology, 16, 237-259.

Wienand, J. (2012). Der Kaiser als Sieger. Metamorphosen triumphaler Herrschaft unter Constantin I. Berlin: Akademie-Verlag.

PhDr. Stanislav Doležal, Ph.D. / dolezal@ff.jcu.cz

Institute of History

University of South Bohemia in České Budějovice, Faculty of Philosophy

Branišovská 31a, 37005 České Budějovice, Czech Republic

This work can be used in accordance with the Creative Commons BY-SA 4.0 International license terms and conditions (https://creativecommons.org/licenses/by-sa/4.0/legalcode). This does not apply to works or elements (such as image or photographs) that are used in the work under a contractual license or exception or limitation to relevant rights. 
